\title{
Jackfruit (Artocarpus heterophyllus Lam) Biggest Fruit with High Nutritional and Pharmacological Values: A Review
}

\author{
Rajneesh Srivastava ${ }^{1}$ and Anu Singh ${ }^{2 *}$ \\ ${ }^{1}$ SMS Horticulture and Incharge ICAR-IIVR- KVK, Deoria, UP India \\ ${ }^{2}$ Department of Food Technology, Allahabad University, Allahabad, UP India \\ *Corresponding author
}

\begin{abstract}
A B S T R A C T
\section{Keywords}

Jackfruit, Artocapus heterophyllus, nutritional, pharmacological values

Article Info

Accepted:

10 July 2020

Available Online:

10 August 2020

Jackfruit (Artocarpus heterophyllus Lam) is a largest fruited evergreen tree possibly indigenous to the rain forests of the Western Ghats in the Southwestern parts of India It is used as staple food in India and commonly known as kanthal, kathal, kathar appears in market during spring to summer. Jackfruit is an important underutilized fruit and often called the poor man's fruit commonly consumed foods in India from the ancient time by value addition of its fruits Jackfruit contains more protein, calcium, iron, vitamins and other essential nutrients when compared to the common fruits Jackfruit is also used as a traditional medicine for the treatment of asthma, ulcers, wound healing, dermatitis, cough, hypertension, nervousness, and constipation. In the different studies Anti-inflammatory, antibacterial and anti-diabetic properties of A. heterophyllus were also reported. The present review deals with general and chemical profile and its importance including pharmacological and other uses.
\end{abstract}

\section{Introduction}

Jackfruit (Artocarpus heterophyllus Lam) largest tree born tropical fruit in the world belongs to the family Moraceae. It is a monoecious evergreen tree possibly indigenous to the rain forests of the Western Ghats in the Southwestern parts of India (Baliga et al., 2011).) . It is used as staple food in India and commonly known as kanthal, kathal, kathar appears in market during spring to summer. It is abundantly grown in India, Bangladesh Malaysia, Indonesia, Thailand, Philippines and Sri
Lanka (Baliga et al., 2011), and in many parts of Southeast Asia (Rahaman et al., 1999). Jackfruit is the national fruit of Bangladesh and Indonesia (Matin, 2015). The word jackfruit comes from portguesa word jaca which is derived from Malayalam word chakka. Among the tropical fruits, Jackfruit is an important underutilized fruit and often called the poor man's fruit commonly consumed foods in India from the ancient time by value addition of its fruits (Arora and Parley 2016). Tender green fruit is used as a vegetable and the juicy pulp of the ripe fruit is eaten fresh as dessert and used in fruit salads 
(Samaddar, 1985). The seeds are eaten cooked, roasted, or fried (Sreeletha et al., 2018). In recent times jams, beverages, candies, preserves, and dehydrated forms are other industrial uses for the jackfruit (Nair et al., 2013). Jackfruit is also used as a traditional medicine for the treatment of asthma, ulcers, wound healing, dermatitis, cough, hypertension, nervousness, and constipation (Abdul and Martin 2015). In the different studies Anti-inflammatory, antibacterial (Khan et al., 2003) antioxidant (Ko et al., 1998) and anti-diabetic properties (Fernado et al., 1991) of A. heterophyllus were also reported. The phenolic types of compounds were mainly reported as the chemical constituent of Artocarpus species (Hakim et al., 2006). It can slow down aging and cell degeneration. Jackfruit can also provide protein and carbohydrates for the body, which will result in more strength for the individual. Jackfruit contains more protein, calcium, iron, vitamins and other essential nutrients (Table 1) when compared to the common fruits (Prem et al., 2015).

\section{Origin}

The Jackfruit is originated from India; being its natural habitat in the rain forest of Western Ghats in the Southwestern part of India. Some authors argue that Jackfruit native to the rainforests of Malaysia. (Mowry et al., 1958).

\section{Distribution}

It is distributed in many parts of the tropics; warm and moist regions (Bose, 1985) particularly in Asia, Africa, and South America (Abdul and Martin 2015). Haq (2006) reported that nowadays, it is an important crop of India, Burma, China, Sri Lanka, Malaysia, Indonesia, Thailand, and the Philippines. It has been introduced to many Pacific islands since post European contact and is of particular importance in Fiji, where there is a large population of Indian descent (Prakash et al., 2009). The Jackfruit plant was brought into Africa by Arabs and afterwards into South America and has got acclimatized in Mexico also. In India the jackfruit is growing in the Jharkhand, Bihar, West Bengal, Uttar Pradesh, Orissa, Chhattisgarh, Andhra Pradesh, Tamil Nadu, Kerala, Goa, Maharashtra, Karnataka and other states in the Eastern and Southern parts of the country (Ranasinghe et al., 2019).

\section{Botanical Description}

The jackfruit scientifically known as Artocarpus heterophyllus (Table 2) is close relative of cempedak (Artocarpus champeden), breadfruit (Artocarpus altilis) and tarap (Artocarpus adoratissimus) which belongs to the family moraceae (Haq 2006). The word Artocarpus is a compilation of two Greek words, artos, which means bread, and karpos, which means fruit (Jones et al., 2013). The species nickname of jackfruit, heterophyllus, is a compilation of two Greek words, hetero, meaning different, and phyllus, which means leaf (Gupta 2011). This implies existing variation in the shape and size of the leaves. Jackfruit (Raihandhany et al., 2018)

\section{The Tree}

Jackfruit is a, handsome evergreen tree grows in the tropics typically attains a height of, 10$20 \mathrm{~m}$ and a stem diameter of $30-80 \mathrm{~cm}$. It has a relatively short trunk with heavy side branching usually begins near the ground and appears a very dense treetop. Stem of this plant is straight rough whereas bark is green or black, $1.25 \mathrm{~cm}$ thick. The canopy shape is usually conical or pyramidal in young trees and becomes spreading and domed in older trees. All parts of the tree exude sticky white latex when wounded. Leaves are Leathery, elliptic to ovate stiff, large (upto $16 \mathrm{~cm}$ long) in length alternate, entire, simple glossy deep 
green, often deeply lobed on young shoots of juvenile (Burkill, 1997). Jackfruit timber is a good wood for furniture, construction material, and musical instruments since it resists bacterial, fungal and termite attacks (Orwa et al., 2001).

\section{Flowers}

This species is monoecious greenish flowers, having male and female inflorescences in separate flower heads. Female spike appears on stout stems that sprout from older branches and the trunk. Male spikes are found on younger branches above female spikes. Male spikes are dense, fleshy, cylindrical to club shaped, and up to $10 \mathrm{~cm}$ (4 in) in length. Flowers are tiny, pale green when young, turning darker with age. Female flowers are larger, elliptic or rounded, with a tubular calyx. The flowers are reportedly pollinated by insects and wind, with a high percentage of crosspollination (Sharma 1964).

\section{Fruits}

Jackfruit (Artocarpus heterophyllus Lam) produces heavier yield than any other tree species, and bear the largest known edible fruit (up to $35 \mathrm{~kg}$ ) The heavy oblong-cylindrical fruit is borne primarily on short stems from the trunk and interior part of main branches is considered to be califlorous The fruits are compound or multiple fruit (syncarp) with a green to yellow brown exterior rind that is composed of hexagonal, bluntly conical carpel apices that cover a thick, rubbery, whitish to yellowish wall. They are typically $30-40 \mathrm{~cm}$ in length but sometimes up to $90 \mathrm{~cm}$ with the diameter 13 50 centimeters. Commonly jackfruit weighted 4.5-30 kg, although a weight of $50 \mathrm{~kg}$ has been also reported (Matin 2015). They take 3-6 months to reach maturity. In the Northern Hemisphere, main season for its maturing is between March and September. A few fruits mature in winter. Jackfruit has a relatively high productivity, 10-200 fruits about 25.71 $\mathrm{t} / \mathrm{ha}$. The compound fruit of jackfruit is made of three parts viz., bulb, seeds and the rind i.e. 30-32, 18 and 50-55 percent respectively (Srivastava et al., 2017). The ripe jackfruit is sweet and has an exotic flavour considered being delicious and nutritious fruit (Swami et al., 2016) and it comprises carpel, seed embedded in carpel and the skin, rind, sheath, core and unfertilized floral parts or undeveloped perianths.

\section{Seeds}

Jackfruit is composed of rind, edible bulbs of yellow flesh and seeds. Seeds of jackfruit are light brown to brown in color, rounded, 2-3 $\mathrm{cm}$ in length by $1-1.5 \mathrm{~cm}$ in diameter, and enclosed in a thin, whitish membrane (Menaka et al., 2011). Madruga et al., 2014 reported that well succulent, aromatic and flavorful yellow sweet jackfruit bulbs contains about 100 to 500 seeds, which represent around 8 to $15 \%$ of the total fruit weight. Most of the time, the seeds are left untreated or discarded as wastes due to the bland taste and texture of the seeds (Kooh et al., 2016) however, are far less utilized with occasional uses as dessert, minor ingredients in culinary recipes or eaten as a snack after boiling, steaming or roasting (Sy Mohamad et al., 2019).

\section{Value addition of Jackfruit}

Sharma et al., 2014 stated that Value addition is the process of increasing the economic value and consumer appeal of an agricultural product by changing or transforming its original state Various value-adding technologies such as processing and preservation techniques, dehydration and drying technology, freezing technology, packing, labeling, etc. can be applied to agricultural produce to increase its value.. 
Jackfruit has great potential for value addition for minimizing post-harvest loses and enhancing the non-seasonal availability (Satheeshan et al., 2019). The value added products prepared from different parts of jackfruit are presented in Table 3

\section{Nutritional Value of the jackfruit}

Jackfruit contain high amount of vitamins and minerals (Table 2). The fruit is rich in carotene and carbohydrates and moderately rich in ascorbic acid (Hossain et al., 1979). Jackfruit also contains minerals like calcium and potassium and Vitamin B complex group like thiamin, riboflavin, and Niacin and. The seeds of jackfruit are reported to be more nutritious than its bulb. Seeds are rich in protein, carbohydrate fat, potassium and with fair amount of phosphorus and calcium (Rahim and Quaddus, 2000). Jackfruits are a good source of vitamin C. According to United State of Agriculture Department report (2016) Jackfruit has the unique nutritional values (table 4)

\section{Phytonutrients and their health benefit}

The phytonutrients can prevent the formation of cancer cells in the body, can lower blood pressure, can fight against stomach ulcers, and can slow down the degeneration of cells that make the skin look young and vital Sajesh et al., 2015. The phytonutrients present in jackfruit are presented in Table 5.

Table.1 Nutritional profile of various fruits (values per $100 \mathrm{~g}$ )

\begin{tabular}{|c|c|c|c|c|c|}
\hline Nutrient & Jackfruit & Pineapple & Mango & Banana & Fig \\
\hline Energy (kcal) & 95 & 50 & 60 & 89 & 74 \\
\hline Carbohydrates (g) & 23 & 13 & 15 & 22.84 & 19.18 \\
\hline Sugars (g) & 19.08 & 9.85 & 13.7 & 12.23 & 16.26 \\
\hline Dietary fiber (g) & 1.5 & 1.4 & 1.6 & 2.6 & 2.9 \\
\hline Fat (g) & 0.64 & 0.12 & 0.38 & 0.33 & 0.30 \\
\hline Protein (g) & 1.72 & 0.54 & 0.82 & 1.09 & 0.75 \\
\hline Thiamine (mg) & 0.105 & 0.079 & 0.028 & 0.031 & 0.060 \\
\hline Riboflavin (mg) & 0.055 & 0.032 & 0.038 & 0.073 & 0.050 \\
\hline Niacin (mg) & 0.92 & 0.5 & 0.669 & 0.665 & 0.400 \\
\hline Pantothenic acid (mg) & 0.235 & 0.213 & 0.197 & 0.334 & 0.300 \\
\hline Vitamin B $\mathbf{( m g}(\mathbf{m g})$ & 0.329 & 0.112 & 0.119 & 0.4 & 0.113 \\
\hline Folate (jg) & 24 & 18 & 43 & 20 & 6 \\
\hline Vitamin C (mg) & 13.8 & 47.8 & 36.4 & 8.7 & 2.0 \\
\hline Calcium (mg) & 24 & 13 & 11 & - & 35 \\
\hline Iron (mg) & 0.23 & 0.29 & 0.16 & 0.26 & 0.37 \\
\hline Magnesium (mg) & 29 & 12 & 10 & 27 & 17 \\
\hline Manganese (mg) & 0.043 & 0.927 & 0.063 & 0.27 & 0.128 \\
\hline Phosphorous (mg) & 21 & 8 & 14 & 22 & 14 \\
\hline Potassium (mg) & 448 & 109 & 168 & 358 & 242 \\
\hline Sodium (mg) & 2 & 1 & 1 & 1 & 1 \\
\hline Zinc (mg) & 0.13 & 0.12 & 0.09 & 0.15 & 0.15 \\
\hline Water (g) & 73.5 & 86.00 & 81.81 & 74.91 & 79.06 \\
\hline
\end{tabular}

Source: Adapted from United States Department of Agriculture (2016, May) report 
Table.2 Scientific nomenclature of Jackfruit (Singh et al., 1963)

\begin{tabular}{|l|l|}
\hline Kingdom & Plantae planta, plantes, plants, vegetal \\
\hline Subkingdom & Tracheobionta, vascular plants \\
\hline Super division & Embryophyta \\
\hline Division & Magnoliophyta, angiosperms, flowering plants, phanérogames \\
\hline Class & Magnoliophyta dicots, dicotylédones, dicotyledons \\
\hline Subclass & Alismidae / Hamamelidae \\
\hline Order & Rosales/ Urticales \\
\hline Family & Moraceae, mulberries \\
\hline Genus & Artocarpus breadfruit \\
\hline Species & Heterophyllus `Artocarpus heterophyllus Lam \\
\hline
\end{tabular}

Table.3 Value added food product made by jackfruit

\begin{tabular}{|l|l|}
\hline Stages of fruit & Value added products \\
\hline Unripe & $\begin{array}{l}\text { Pickle, Chips, Papad, Brined Jackfruit, RTC Jackfruit, Dehydrated Jackfruit, Culinary } \\
\text { preparations, Cutlets, Biryani }\end{array}$ \\
\hline Half ripe fruit & Candy, Preserve \\
\hline Fully ripe fruit & $\begin{array}{l}\text { Jam, Leather, Rind Jelly, Squash, Nectar, Canned Bulbs, RTE (Ready-to-eat) Bulbs, RTS } \\
\text { (Ready-to-serve) Drinks, Chutney, Toffee, Wine, Halwa, Kheer, Gulab Jamun, Icecream, } \\
\text { Custard, Cake, Freeze dried pulp }\end{array}$ \\
\hline Seeds & Seed powder, Starch flour, Culinary preparation, Pakoda, Kheer \\
\hline
\end{tabular}

Source: Srivastava et al., (2017)

Table.4 Nutritional profile of jackfruit (100 g edible portion)

\begin{tabular}{|c|c|c|c|c|}
\hline Sr. No & Composition & Young fruit & Ripe fruit & Seed \\
\hline A & \multicolumn{4}{|l|}{ Proximate analysis } \\
\hline 1 & Water $(\mathrm{g})$ & 76.2 to 85.2 & 72.0 to 94.0 & 51.0 to 64.5 \\
\hline 2 & Protein $(\mathrm{g})$ & 2.0 to 2.6 & 1.2 to 1.9 & 6.6 to 7.04 \\
\hline 3 & Fat $(\mathrm{g})$ & 0.1 to 0.6 & 0.1 to 0.4 & 0.40 to 0.43 \\
\hline 4 & Carbohydrate (g) & 9.4 to 11.5 & 16.0 to 25.4 & 25.8 to 38.4 \\
\hline 5 & Fibre $(\mathrm{g})$ & 2.6 to 3.6 & 1.0 to 1.5 & 1.0 to 1.5 \\
\hline 6 & Total sugars (g) & - & 20.6 & - \\
\hline B & \multicolumn{4}{|l|}{ Minerals } \\
\hline 1 & Total minerals (g) & 0.9 & 0.87 to 0.9 & 0.9 to 1.2 \\
\hline 2 & Calcium (mg) & 30.0 to 73.2 & 20.0 to 37.0 & 50.0 \\
\hline 3 & Magnesium (mg) & & 27.0 & 54.0 \\
\hline 4 & Phosphorus (mg) & 20.0 to 57.2 & 38.0 to 41.0 & 38.0 to 97.0 \\
\hline 5 & Potassium (mg) & 287 to 323 & 191 to 407 & 246 \\
\hline 6 & Sodium (mg) & 3.0 to 35.0 & 2.0 to 41.0 & 63.2 \\
\hline 7 & Iron $(\mathrm{mg})$ & 0.4 to 1.9 & 0.5 to 1.1 & 1.5 \\
\hline C & Vitamins & & & \\
\hline 8 & Vitamin A (IU) & 30 & 175 to 540 & 10 to 17 \\
\hline 9 & Thiamine (mg) & 0.05 to 0.15 & 0.03 to 0.09 & 0.25 \\
\hline 10 & Riboflavin (mg) & 0.05 to 0.2 & 0.05 to 0.4 & 0.11 to 0.3 \\
\hline 11 & Vitamin C (mg) & 12.0 to 14.0 & 7.0 to 10.0 & 11.0 \\
\hline
\end{tabular}

Source: Gunasena et al., (2000), Swami et al., (2012) 
Table.5 Phytonutrients in different parts of Jackfruit

\begin{tabular}{|c|c|c|c|}
\hline S. $\mathbf{N}$. & Phytonutrients & Phytochemicals & Plant Part \\
\hline 1. & Carbohydrate & Starch, Sugar, Dietary fiber & Fruit,Seed \\
\hline 2. & Protein & $\begin{array}{l}\text { Arginine, Cystine, Histidine, Leucine, Lysine, Methionine, } \\
\text { Threonine, and Tryptophan }\end{array}$ & Fruit,Seed \\
\hline 3. & Mineral & Calcium,Magnesium,Phosphurus,Potaasium,Sodium,Iron & Seed,Fruit \\
\hline 4. & Vitamins- & Vitamin A, Vitamin E,Thiamine, Ribofalvin, Vitamin C & Fruit \\
\hline 5. & FattyAcids & Capric,Myristic,Lauric,Palmitic,Oleic,Stearic & Fruit \\
\hline 6. & Organic acid & Acid-Malic acid,Citric acid & Fruit \\
\hline 7. & Carotenoids- & $\begin{array}{l}\text { 2-carotene, 1-carotene, 1-Zeacarotene, Dicarboxylic } \\
\text { Carotenoid }\end{array}$ & Fruit \\
\hline 8. & Flavonoids & $\begin{array}{l}\text { Artocarpetin, Artocarpetin, Artonins } \\
\text { Artocarpanone, Artocarpesin }\end{array}$ & Fruit \\
\hline 9. & Lectin & Jacalin & Seed \\
\hline 10. & Volatiles & Isopentylisovalereate, Butyl isovalearte, Butyl Acetate & Seed,Fruit \\
\hline 11. & Tannins & & Stem,Leaf \\
\hline
\end{tabular}

Source: Trindade and Lopes, 2006; Arora and Parley, 2016

Table.6 Pharmacologiacal Activities of Artocarpus heterophyllus (Arora and Parley 2016)

\begin{tabular}{|c|c|c|c|}
\hline Pharmacological activities & Plant parts & Phytoconstituent & Reference \\
\hline \multicolumn{4}{|l|}{ 1. Anti-infective } \\
\hline Anti-Fungal & Leaf,Seed & Chalcone & Trinidade and Lopes (2006) \\
\hline Anti-viral & Seed & Oxyresveratrol & Chaunasa and Lipipun, (2008) \\
\hline Anti-bacterial & $\begin{array}{l}\text { Bark of stem,root, } \\
\text { leaves and fruit }\end{array}$ & Isoprenyl Flavone & Loizzo and Tundis, (2010) \\
\hline 2. Anti-cancer & Wood & $\begin{array}{l}\text { Isoprenoid } \\
\text { Flavonoids }\end{array}$ & Lanskey and Pawlus, (2008) \\
\hline \multicolumn{4}{|l|}{ 3. Inflammotary diseases } \\
\hline Anti-inflammatory & Fruit & Flavonoids & Chanda and Dutta, (2009); \\
\hline Wound healing & Leaf & Lectin & Chahud and Haddad, (2009) \\
\hline 4. Anti-Diabetic & Leaf & Prenyl Flavonoids & $\begin{array}{l}\text { Kotowaroo and Mahomoodally, } \\
\text { (2006) }\end{array}$ \\
\hline \multicolumn{4}{|l|}{ 5. Miscellaneous } \\
\hline Anti-Oxidant & Fruit,Seed & Prenyl Flavones & Gupta et al., (2011) \\
\hline Anti-Malarial & $\begin{array}{l}\text { Bark of root and } \\
\text { stem }\end{array}$ & $\begin{array}{l}\text { Prenylated } \\
\text { Flavonoids }\end{array}$ & $\begin{array}{l}\text { Boonlaksiri and Kong5seree, } \\
(2000)\end{array}$ \\
\hline Anti-Diarrheal & $\begin{array}{l}\text { Bark of root and } \\
\text { stem }\end{array}$ & $\begin{array}{l}\text { Prenylated } \\
\text { Flavonoids }\end{array}$ & Henirich and Heneka, (2005) \\
\hline Anti-carcinogenic & Leaf & Flavonoids & Sato and Fujii, (1996) \\
\hline Anti-Platelets & Root, Seed & Flavonoids & Jagpat and Bapat, (2010) \\
\hline Anti-Tubuculer & Root,Stem & $\begin{array}{l}\text { Prenylated } \\
\text { Flavonoids }\end{array}$ & Boonphong and Kittakoop, (2007) \\
\hline Anti-atherosclerosis & Fruit, Root & Flavonoids & Jagpat and Bapat, (2010) \\
\hline Anti-arthritic & Leaf, Fruit & Flavonoids & Ngoc and Catrina, (2005) \\
\hline
\end{tabular}

Source: (Arora and Parley 2016) 


\section{Carbohydrates}

Jackfruit contains more carbohydrates and sugars as it ripens Singh et al., 1991 reported that jackfruit perianth and seed contains a high percentage of starch. The starch and dietary fiber content of the flesh increase with the fruit maturity (Rahman et al.1999). Chrips et al., (2008) find carbohydrate variation from $37.4 \%$ to $42.5 \%$ in different varieties of jackfruit seed. Swami et al., 2012 reported that low caloric content (94) in $100 \mathrm{~g}$ of jackfruit.

\section{Proteins}

The pulp of ripe jackfruit contains $1.9 \mathrm{~g}$ proteins per 100g.and many amino acids like arginine, cystine, histidine, leucine, lysine, methionine, threonine, and tryptophan (Theivasanthi et al.,2011). The protein concentration of the jackfruit seeds may vary from 5.3 to $6.8 \%$ (Chrips et al., 2008). According to Swami et al., (2012).The protein content has ranged from 0.57 to $0.97 \%$ and $17.8-37 \%$ in the pulp and seed of different varieties of jackfruit.

\section{Fat}

It contains no saturated fats or cholesterol making it a healthy fruit. Artocarpus heterophyllus is composed of more of the saturated fatty acids with a total value of $65.25 \%$. The low fatty acid content in jackfruit is reported by Gunasena (1993) estimated fat content of $0.1-0.4 \%$ and Sreeletha et al., (2018) also reported similar fat content of 0.4 per cent.

\section{Vitamins}

Jackfruit is higher in Vitamin A, Vitamin E, Vitamin B5 and Vitamin B6 and it is one of the rare fruits which rich in vitamin- B complex (Burkill, 1997) and contains very good amounts of vitamin B6 (pyridoxine), B3 (niacin), riboflavin and folic acid (Narsimhan, 1990) Jackfruit is rich in vitamin C (Swami et al., 2012).Tiwari and Vidyarthi, (2015) Evaluated that vitamin contents vary in different maturity stages of jackfruit. Niacin, known as vitamin $B_{3}$, necessary for energy metabolism, nerve function, and the synthesis of certain hormones (Soobrattee et al.,2005). Another heart-friendly property found in the jackfruit is due to vitamin B6 that helps reduce homocysteine levels in the blood thus lowering the risk of heart disease (Fernando et al., 1991).

\section{Minearals}

The ripen jackfruit contains minerals such as calcium, magnesium (Tiwari and Vidyarthi, 2015) Samaddar, (1985) has recorded that every $100 \mathrm{~g}$ flakes of ripe jackfruits contains 287-323 mg, potassium, 30.0-73.2 $\mathrm{mg}$ calcium. Sundarraj and Ranganathan (2017) also reported that jackfruit have good amount of minerals.

\section{Pharmacological Activities}

Jackfruit is a tropical tree, which has numerous health benefits of jackfruit including anti-carcinogenic, anti-microbial, anti-fungal, anti-inflammatory, wound healing, and hypoglycemic properties (Sofowara, 1993). Jackfruit contains, phytonutrients including lignins, isoflavones, and saponins. These phytonutrients have anticancer, antiulcer, and anti-aging properties (Baliga et al., 2011). Sundarraj and Rangnathan (2017) reported that alkaloids, flavonoids, carbohydrates, proteins and triterpenoids the active compounds presence in jackfruit. The rich bioactive profile of jackfruit makes it a highly nutritious and desirable fruit crop. The different pharmological activities are presented in Table 6 


\section{Future Prospect}

Quality and quantity of food have become important issue at the global level. Jackfruit is grown mainly on homestead farms and it produces multiple products for food, feed, and industry. It is also contributing towards soil management for sustainable environments. Nowadays, number of scientific and economic interest emerged to commercialized and promoting jackfruit products. There are high levels of vitamins and minerals have been recorded in jackfruit. Being nutritionally rich it can be good candidate to meet the nutritional deficiency. However, it is considered as an underutilized fruit in commercial scale, mainly due to higher percentage inedible portion which leads to more waste generation, difficulty in peeling and separation of edible bulbs from the rind, lack of knowledge on proper postharvest practices, and inadequate processing facilities in regions where they are grown. There is a great need of further research on enhancing its shelf life and its commercialization and to promote this fruit. However, it is considered as an underutilized fruit in commercial scale hence, adhering to correct post harvest practices and conversion of jackfruit into minimally processed products. Using standardized jackfruit products offer consumers a way of reaping the broad spectrum of health benefit of this fruit.

\section{References}

Abdul, M. and Martin K.A. (2015). Poor man's fruits: Now a miracle food. Food Chem. 5(\$): 123-134.

Arora, T. and Parle A. (2016). Jackfruit: A health boon. Int. J. Res. Ayurveda Pharm. 7(3: 59-64.)

Baliga M.S., Shivashankara, A.R., Haniadka R. Dsouza J. and. Bhat H.P. (2011) Phytochemistry, nutritional and pharmacological properties of
Artocarpus heterophyllus Lam. (jackfruit): A review, Food Research International: 44(9). 1800- 1811.

Boonphong, S., and Kittakoop P (2007). Antituburcular and antiplasmodial prenylated flavones from the root of Artocarpus altilis. Chiang Mai J. of Sci.34:339-344.

Bose, T.K. (1985). "Jackfruit," in Fruits of India: Tropical and Subtropical, B.K., Mitra, Ed., 488-498, Naya Prokash, Calcutta,India,

Burkill HM (1984). The useful plants of West Tropical Africa vol 1. Families A-D. Royal Botanical Garden kew.. 441415p.

Chahud, F. and Haddad A. (2009). The lactin $\mathrm{KM}+$ induces corneal epithelial wound healing in rabbits. Int. J. of experi. Pathol. 90:166-173.

Chanda, I and Dutta S.K. Anti-inflammatory activity of a protease extracted from the fruit tem latex of the plant Artocarpus heterophyllus Lam. Research journal of pharmacology and pharmacodynamic, 1:70-72.

Chauanasa, T. and Lipipum V. Anti-Herpes simplex virus activity of oxyresveratrol derived from Thai medicinal plant. Antiviral research; 80: 62-70.

Chrips, N.R., Balasingh R.G.S. and Kingston C (2008). "Nutrient constituens of negleted varieties of Artocarpus heterophyllus Lam.from Kanyakumari district, South India,"Journal of Basic and Applied Biology, 2:.36-37,

Fernando, M.R, Wickramasinghe N, Thabrew M.I. 1991. Effect of Artocarpus heterophyllus and Asteracanthus longifolia on glucose tolerance in normal human subjects and in maturityonset diabetic patients. J Ethnopharmacol 1(3):277-82.

Gupta, R. (2011). Plant Taxonomy: Past, Present, and Future. New Delhi: The Energy and Resource Institute (TERI) 
Gupta, D., Mann, S., Sood A. and Gupta R.K. (2011). Phytochemical, nutritional and antioxidant activity evaluation of seeds of jackfruit (Artocarpous heterolphyllus Lam.) Int. J. Pharm. Biosci., 2(4), 336-345.

Hakim, E.H., Achmad S.A., Juliawaty L.D., Makmur L., Syah Y.M., Aimi N., Kitajima M., Takayama H.and Ghisalberti E.L. (2006). Prenylated flavonoids and related compounds of the Indonesian Artocarpus (Moraceae). Journal of Natural Medicines 60(3): 161-184.

Haq N, Jackfruit (Artocarpus heterophyllus) in Tropical Fruit Trees, J. T. Williams, R. W. Smith, and Z. Dunsiger, Eds., Southampton Centre for Underutilised Crops, University of Southampton, UK, 2006.

Henirich, M. and Heneka B. (2005) Spasmolytic and Antidiarrhoeal properties of the Yucatecmayan medicinal plant Casmiroatetiameria. The J. of pharmacy and pharmacology. 57:1081-1085.

Hossain, M.M., Haque A. and Hossain, M. (1979). Nutritive value of jackfruit. Bangladesh J. Agril., 1(2): 9-12.

Jagpat, U., and Bapat V. (2010) Evaluation of antioxidant capacity and phenol content in jackfruit. Plant foods for human nutrition, 65:99-104

Jones A.M.P., Murch S.J., Wiseman J., Ragone D. (2013). Morphological diversity in breadfruit (Artocarpus, Moraceae): Insights into domestication, conservation, and cultivar identification. Genetic Resources and Crop Evolution 60: 175-192.

Ko, H.H. and Yang S.Z. (2005). Cytotoxic prenylflavinoids from Artocarpus elasticus. Journal of natural products 68:1692-1695.

Kooh, M.R.R., Dahri, M.K.D. and Lim, L.B.L. (2016). Jackfruit seed as a sustainable adsorbent for the removal of Rhodamine B dye. J. Environ.and Biotech. Res., 4(1), 7- 16.

Kotowaroo M.I.and Mahomoodally M.F. (2006). Screening of traditional antidiabetic medicinal plant of Mauritius for possible alpha- amylase inhibitory effects invitro. Phytotheraphy research. 20:228-231.

Loizzo, M.R., Tundis,. U. Chandrika, G., Abeysekera, A.M., Menichini, F. and Frega, N.G., (2010) "Antioxidant and antibacterial activities on foodborne pathogens of artocarpus heterophyllus lam. (Moraceae) leaves extracts," Journal of Food Science: 75(5) 291295.

Madruga M.S., Medeiros De Albuquerque F.S., Alves Silva I.R., Silva Do Amara, D., Magnani, M., \& Queiroga Neto, V. (2014). Chemical, morphological and functional properties of Brazilian jackfruit (Artocarpus heterophyllus L.) seeds starch. Food Chemistry: 143 440445.

Matin, A. (2015). A poor man's fruit: Now a miracle food (https://en.wikipedia.org/ wiki/ Jackfruit.

Menaka T., Nagaraja G., Yogesh D.B., Sunil K.U.S. and Prakash, L. (2011). Physicochemical Properties of flour and isolated starch from Jackfruit seeds (Artocarpus heterophyllus Lam.). RGUHS Journal of Pharmaceutical Sciences, 1(1), 58-63.

Mowry H., Toy L.R., and. Wolfe H.S. (1958). Miscellaneous Tropical and Subtropical Florida Fruits, G. D. Ruehle, Ed. Agricultural Extension Service, University of Forida, Gainesville, Florida, Bulletin156Aedition,pp.28

Nair, S.S, Madembil C., Nair P., Raman S. and Veerabadrppa B (2013) Comperative analysis of the antibacterial activity of some phytolactins.int. Curr. Pharma 2(2):18- 
22.

Ngoc D. and Catrinaa A.(2005). Inhibition of Artocarpus tonkinensis of the development of collagen- induced arthritis in rats. Scandinavin J. of immuno. 61:234-241.

Prakash, O., Kumar, R., Mishra, A and Gupta, R. (2009) "Artocarpus heterophyllus (Jackfruit): An overview," Pharmacognosy Reviews: 3(6), pp.353358.

Okwu D.E. (2001). Evaluation of the chemical composition of indigenous spices and flavouring Agents. Global J. Pure Appl. Sci. 7(3): 455459.

Rahim, M.A. and Quaddus, M.A. (2000).Characterization and grafting performance of different accessions of jackfruit. MS Thesis, Bangladesh Agricultural University, Mymensingh, Bangladesh.

Rahman, M.A., Nahar, N., Mian, A.J., and Moshiuzzaman, M. 1999. Variation of carbohydrate compostion of two forms of fruit from jack tree (Artocarpus heterophyllus L) with maturity and climatic condition. Food Chemistry 6 (9):1-7.

Raihandhany R., Wicaksono A., Jaime A. and da Silva T. (2018). Jackfruit (Artocarpus heterophyllus) and Breadfruit (A. altilis): Phytochemistry, Pharmacology, Commercial Uses and Perspectives for Human Nourishment. Journal of Tropical Biology and Conservation 15: 61-80

Sajesh J.V., Jiby N.K., Ajesh J.M., Benchamin C.K., Renjith A., Alen J.M., N.A., Deenamol T., Riny S.T., Nijamol V. and Sophyiamol, J. (2015). Chemistry and medicinal properties of jackfruit (artocarpus heterophyllus): A review on current status of knowledge. International Journal of Innovative Research and Review 3(2), 83-95.

Samaddar H.M. (1985). Jackfruit. In: Bose
TK, Mishra S.K, edited. Fruits of India: tropical and subtropical. Culcutta, India: Naya Prokash. p 638-49.

Satheeshan K.N., Seema B.R. and Meeramanjusha A.V. (2019) Development of Jackfruit Seed Flour Incorporated Jackfruit Halwa (Artocarpus Heterophyllus Lam). International Journal of Agriculture Sciences: 11(22) 9212-9215.

Sato M. and Fujii T. (1996). Flavones with antibacterial activity against cariogenic bacteria. Journal of ethnopharmocology 54:171-176.

Sharma J.P., Upadhyay, S., Chaturvedi, V.K. and Bharadwaj, T. (2014). Enhancing farm profitability through food processing and value addition. In: Shukla, J.P. Technologies for Sustainable Rural Development: Having Potential of Socioeconomic Upliftment (TSRD-2014). Published by allied Publisher Pvt.Ltd. India.p. 88.

Singh A., Kumar S., and. Singh I.S. (1991), "Functional properties of jackfruit seed flour,'Lebensm-Willu Technology, vol.24.373-374.

Singh S., Krishnamurthi S. and Katyal S, (1963). Fruit Culture in India, ICAR, New Delhi, India.

Sofowara A (1993). Medicinal plants and Traditional medicine in Africa. Spectrum Books Ltd, Ibadan, Nigeria. p. 289.

Soobrattee M.A., Neergheen V.S., LuximonRamma A., Aruoma O.I., Bahorun T. (2005). Phenolics as potential antioxidant therapeutic agents: mechanism and actions. Mutant Res Fundam Mol. 579: 200-213.

Sreeletha AS1, Lini JJ, Dhanyalekshmi CS, Sabu KR and Pratap Chandran R. (2018). Phytochemical, Proximate, Antimicrobial, Antioxidant and FTIR Analyses of Seeds of Artocarpus heterophyllus Lam. Adv Biotech \& 
Micro 5(1):16-24.

Srivastava A., Bishnoi, S.K. and Sarkar, P.K. (2017). Advances in value addition in jackfruit (Artocarpus heterophyllus Lam.) for food and livelihood security of rural communities of India. Asian J. Hort., 12(1): 160-164.

Sundaraj A.A. and Ranganathan T.V. Phytochemical Screening And Spectroscopy Analysis Of Jackfruit (Artocarpus integer Thumb.) Peel (2017) Int. Res. J. Pharm., 8 (9) 151159.

Swami B.S., Thakor N.J., Haldankar P.M. and Kalse S.B (2012). Jackfruit and Its Many Functional Components as Related to Human Health: A Review. Comprehensive Reviews in Food Science and Food Safety 11(6), 565576.

Theivasanthi T. and Alagar M. (2011). An insight analysis of nano sized powder of jackfruit seed. Nano Bio-medicine and Engineering 3(3), 163-168.

Tiwari A.K.and.Vidyarthi A.S. (2015). "Nutritional Evaluation of Various Edible Fruit Parts of Jackfruit (Artocarpus heterophyllus) at Different Maturity Stages,'International Journal of Chemical and Pharmaceutical Review and Research: 1.21-26.

Trinidade M. and Lopes J. Structural characterization of novel chitin-binding lectins from the genus Artocarpus and their antifungal activity. Biochimica et biophysica acta, 1764: 146-152.

United States Department of Agriculture USDA. Natural Resources Conservation Service - NRCS. (2016). The Plants Database. Greensboro: National Plant Data Team.

\section{How to cite this article:}

Rajneesh Srivastava and Anu Singh. 2020. Jackfruit (Artocarpus heterophyllus Lam) Biggest Fruit with High Nutritional and Pharmacological Values: A Review. Int.J.Curr.Microbiol.App.Sci. 9(08): 764-774. doi: https://doi.org/10.20546/ijcmas.2020.908.082 